\title{
Evaluation of Effectiveness of an Informational Booklet on Prevention of Osteoporosis in Terms of Knowledge, Attitude and Expressed Practices of Working Women
}

\author{
Nisha M Varghese ${ }^{1}$,Vinay Kumari ${ }^{2}$, Mercy Madanlal ${ }^{3}$ \\ ${ }^{I}$ M.sc Nursing(Medical-Surgical)Maharishi Markandeshwar College of Nursing,Mullana, Ambala,Haryana \\ ${ }^{2}$ Assistant Professor, Maharishi Markandeshwar College of Nursing, Mullana, Ambala, Haryana \\ ${ }^{3}$ Ex. Assistant Professor,Maharishi Markandeshwar College of Nursing,Mullana, Ambala, Haryana
}

\begin{abstract}
According to World Health Organization (WHO), osteoporosis is second only to cardiovascular disease as a global healthcare problem. Health education on osteoporosis is critical for young women to become better aware of the causes and symptoms of osteoporosis, given the critical long-term effects of this illness for women. The main objective of the study was to assess and compare the knowledge, Attitude and Expressed practices of working women regarding prevention of osteoporosis in experimental and comparison group.Quasi experimental non-equivalent control group pretest posttest design was used. Thestudy was conducted at selected institutions of MM University, Mullana, Ambala, Haryana. 100 female teaching faculties were selected using convenience sampling. Structured knowledge questionnaire, attitude scale and expressed practices scale was used to assess the knowledge, attitude and expressed practices of working women regarding prevention of osteoporosis. Descriptive and inferential statistics were used to analyze the data. The findings of the study indicated that the mean post test knowledge, attitude and expressed practice score of working women $(29.44 \pm 3.52,100.16 \pm 6.78,52.20 \pm 4.3)$ in experimental group was significantly higher than the mean post test knowledge, attitude and expressed practice score $(17.48 \pm 4.47,84.10 \pm 5.85,46.14 \pm 7.48)$ in comparison group. Positive significantrelationship $(r=0.59)$ was found between post test knowledge and attitude of working women in experimental group. A significant association was found between level of pos test knowledge with religion ( $t=7.55)$, post test attitude with religion $(t=10.04)$ and source of knowledge $(t=5.25)$ in experimental group.Informational booklet is an effective strategy in enhancing knowledge, developing favourable attitude, and improving practices of working women regarding prevention of osteoporosis.
\end{abstract}

Keywords: Informational booklet, osteoporosis, working women, Experimental and control group.

\section{Introduction}

Osteoporosis is a major health burden affecting millions of people worldwide. ${ }^{1}$ It is a global problem which is increasing in significance as the population of the world both grows and ages. Osteoporosis ranks as one of the common diseases of aging after diabetes, hyperlipidemia, hypertension and heart diseases. ${ }^{1}$ According to World Health Organization (WHO), osteoporosis is second only to cardiovascular disease as a global healthcare problem and medical studies show a 50-year-old woman has a similar lifetime risk of dying from hip fracture as from breast cancer. ${ }^{2}$ With socio-economic development in many Asian countries and rapid ageing of the Asian population, osteoporosis has become one of the most prevalent and costly health problems in the region. Unsurprisingly, Asia is the region expecting the most dramatic increase in hip fractures during coming decades; by 2050 one out of every two hip fractures worldwide will occur in Asia. 1 out of 8 males and 1 out of 3 females in India suffers from osteoporosis, making India one of the largest affected countries in the world. Osteoporosis can begin as early as age twenty-five, yet the majority of those affected by osteoporosis are postmenopausal women. ${ }^{3}$ Therefore, it is important to promote educational interventions designed for osteoporosis prevention in women. Women in young adulthood in particular will benefit from being informed about how proper nutrition and regular exercise can help them achieve optimal peak bone mass. A study conducted by Leslie and St. Pierre discuss the lack of awareness this age group has of the negative impact that smoking, alcohol abuse, diets low in calcium and Vitamin D, high protein diets, and both physical inactivity and excessive exercise have on their bone structure. Educating these women about what may predispose them to a higher risk of osteoporosis in later years would benefit all young women. Once young women are educated on the risks of osteoporosis and preventive behaviors, they will be able to act on the evidence, which suggests that heightening bone mass in young women through increased calcium intake and increased weight-bearing exercise may help decrease or prevent osteoporosis later in life. ${ }^{4} \mathrm{~K}$ Pande et al conducted a study to assess knowledge about osteoporosis in learned Indian women, identify their source of knowledge and to study the correlation of level of knowledge with other variables. The results shown that the correct definition of osteoporosis was given by $74 \%$, but there was general lack of awareness in all the areas assessed. ${ }^{5}$ 
A study was conducted by Ellen T. Edmonds and Lori W. Turner to assess osteoporosis knowledge, beliefs and preventive behaviours among 321 premenopausal adult women and to identify sources that they would mostly likely utilize to learn more about the disease. The findings revealed that 277 (86\%) of the participants had heard about osteoporosis, but only $3.8 \%$ of them were following adequate exercise and intake of recommended $1,200 \mathrm{mg}$ of calcium per day. They believed that they were unlikely to develop osteoporosis and that osteoporosis is less serious than heart disease and breast cancer. ${ }^{6}$

The majority of osteoporosis prevention programs have been focused on postmenopausal women. In India, there is no such research conducted on prevention of osteoporosis among women before menopause. Moreover various teaching strategies are used to enhance the knowledge regarding osteoporosis among women but the use of informational booklet as a self learning strategy has not been adopted in any of the research studies.So, the investigator found it relevant to evaluate the effectiveness of an informational booklet on knowledge, attitude, and expressed practices of working women regarding prevention of osteoporosis in selected institutions of Ambala, Haryana.

\section{OBJECTIVES OF THE STUDY}

1. To assess and compare the knowledge, Attitude and Expressed practices of working women regarding prevention of osteoporosis in experimental and comparison group.

2. To determine the relationship between knowledge, attitude and expressed practices of working women regarding prevention of osteoporosis in experimental group.

3. To determine the association of level of knowledge, attitude and expressed practices regarding prevention of osteoporosis with selected personal variables.

\section{Material And Method}

The research design used in the study was "Quasi-experimental, Non-equivalent control group pretest posttest design. The population of the present study comprised of working women in selected non-Medical institutions of MM University. After getting ethical approval from institutional ethical committee, formal administrative approval from Registrarand principal of selected institutions of MM University, the data was collected by structured knowledge questionnaire, attitude scale, and expressed practices scale to assessthe pre and post test knowledge, attitude and expressed practices. The Sample of the present study comprised of women working in selected non-medical institutions of MM University, Mullana, Ambala and meets the designated criteria. Both Descriptive and inferential statistics were used for data analysis.

\section{Findings}

Majority of the working women in experimental group (46\%) and in comparison group (44\%) were in the age group of 32- 38 years. Majority of the working women in experimental group (86\%) and in comparison group $(80 \%)$ were Hindus. Most of the working women in both the groups $(76 \%)$ were postgraduates. Majority of the working women in experimental group (56\%) and in comparison group $(50 \%)$ were having family income above Rs 30,000. Majority of the working women in experimental group (84\%) and in comparison group (66\%) were residing outside the campus and $80 \%$ of working women in experimental and $70 \%$ in comparison group were vegetarian. Majority of the working women in experimental group (78\%) and in comparison group (86\%) were married. Majority of working women in experimental group (82\%) and in comparison group $(90 \%)$ reported no history of osteoporosis in the family. Most of the working women in experimental group (96\%) and in comparison group (98\%) were not taking any medications for any kind of illness. Majority of the working women in experimental group (74\%) and in comparison group (94\%) were not having any family member as health professional. It was noted that majority of the working women in experimental group (64\%) and in comparison group (80\%) had no source of knowledge related to prevention of osteoporosis.

The chi square shows that both groups were similar except for place of residence $\left(\chi^{2}=4.32, p=0.04\right)$ and any family member as health professional $\left(\chi^{2}=7.44, p=0.01\right)$ as majority of working women in experimental group (84\%) and only $66 \%$ in comparison group were residing outside the campus. Similarly $26 \%$ of working women in experimental group and only $6 \%$ in comparison group were having family member as health professional before the administration of informational booklet.

Table 1 reveals that before the administration of informational booklet $27(54 \%)$ had below average followed by $14(28 \%)$ of working women had average knowledge. Whereas after the administration of informational booklet $45(90 \%)$ had very good knowledge.

Furthermore, before the administration of informational booklet majority of working women 49 (98\%) had moderately favourable attitude whereas after the administration of informational booklet $38(76 \%)$ had favourable attitude followed by $12(24 \%)$ had moderately favourable attitude. 
Similarly, before the administration of informational booklet $48(96 \%)$ had poor practices followed by $2(4 \%)$ of working women had fair practice. Whereas after the administration of informational booklet most of the working women $42(84 \%)$ were having fair practices.

Table 1 Frequency \&Percentage Distribution of Pretest and Posttest Levels of Knowledge, Attitude and Expressed Practices in Experimental Group

$\mathbf{N}=\mathbf{5 0}$

\begin{tabular}{|c|c|c|c|c|c|}
\hline \multicolumn{6}{|c|}{ Knowledge } \\
\hline \multirow[t]{2}{*}{ Levels of Knowledge } & \multirow[t]{2}{*}{ Range and Percentage of Scores } & \multicolumn{2}{|c|}{ Pretest } & \multicolumn{2}{|c|}{ Posttest } \\
\hline & & $\mathrm{N}$ & $\%$ & $\mathrm{n}$ & $\%$ \\
\hline Very Good & 26- 34 (above75\%) & 02 & 04 & 45 & 90 \\
\hline Good & $21-25(61$ to $75 \%)$ & 07 & 14 & 02 & 04 \\
\hline Average & $18-20(51$ to $60 \%)$ & 14 & 28 & 03 & 06 \\
\hline Below Average & 0-17 (below 50\%) & 27 & 54 & 00 & 00 \\
\hline \multicolumn{6}{|c|}{ Attitude } \\
\hline Levels of Attitude & Range and Percentage of Scores & \multicolumn{2}{|c|}{ Pretest } & \multicolumn{2}{|c|}{ Posttest } \\
\hline & & $\mathrm{F}$ & $\%$ & $\mathrm{n}$ & $\%$ \\
\hline Favourable & $98-130(>75 \%)$ & 01 & 02 & 38 & 76 \\
\hline Moderately Favourable & $66-97(50-75 \%)$ & 49 & 98 & 12 & 24 \\
\hline Unfavourable & $26-65(<50 \%)$ & 00 & 00 & 00 & 00 \\
\hline \multicolumn{6}{|c|}{ Expressed practice } \\
\hline Levels of Expressed practice & Range and Percentage of Scores & \multicolumn{2}{|c|}{ Pretest } & \multicolumn{2}{|c|}{ Posttest } \\
\hline & & $\mathrm{F}$ & $\%$ & $\mathrm{n}$ & $\%$ \\
\hline Poor & $25-37(<50 \%)$ & 48 & 96 & 00 & 00 \\
\hline Fair & $38-56(50-75 \%)$ & 02 & 04 & 42 & 84 \\
\hline Good & $57-75(>75 \%)$ & 00 & 00 & 08 & 16 \\
\hline
\end{tabular}

The data presented in Table 2 shows that the mean pre test knowledge score of working women in experimental group was 16.94 and 16.32 in comparison group with a mean difference of 0.62 . The computed' $t$ ' value obtained (0.49) was found to be statistically not significant at 0.05 level.

Furthermore, the mean pre test attitude score of working women in experimental group was 86.18 and 84.06 in comparison group with a mean difference of 2.12. The computed ' $t$ ' value obtained (0.09) was found to be statistically not significant at 0.05 level.

Similarly, the mean pre test expressed practices scores of working women in experimental group was 49.10and 45.90 in comparison group with a mean difference of 3.20. The computed ' $t$ ' value obtained $(0.06)$ was found to be statistically not significant at 0.05 level.

Therefore, it was inferred that the mean difference in pre test knowledge, attitude and expressed practices score in experimental group and comparison group was not a true difference but by chance. Therefore, both the groups were similar in terms of knowledge, attitude and expressed practices before the administration of informational booklet.

Table 2 Comparison of pre-test Knowledge, Attitude and Expressed PracticesScores in Experimental and comparison Group

$\mathbf{N}=\mathbf{1 0 0}$

\begin{tabular}{|c|c|c|c|c|c|c|}
\hline \multicolumn{7}{|c|}{ Knowledge } \\
\hline Group & Mean & $\mathbf{M}_{\mathrm{D}}$ & SD $_{\mathrm{D}}$ & S.E $E_{M D}$ & 't' & p value \\
\hline Experimental $(n=50)$ & 16.94 & & & & & \\
\hline & & 0.62 & 5.52 & 1.03 & 0.69 & $0.49^{\mathrm{NS}}$ \\
\hline Comparison $(n=50)$ & 16.32 & & & & & \\
\hline \multicolumn{7}{|c|}{ Attitude } \\
\hline Experimental $(n=50)$ & 86.18 & & & & & \\
\hline & & 2.12 & 9.27 & 1.65 & 1.68 & $0.09^{\mathrm{NS}}$ \\
\hline Comparison $(n=50)$ & 84.06 & & & & & \\
\hline \multicolumn{7}{|c|}{ Expressed Practices } \\
\hline Experimental $(n=50)$ & 49.10 & & & & & \\
\hline & & 3.20 & 11.17 & 2.52 & 1.89 & $0.06^{\mathrm{NS}}$ \\
\hline Comparison $(n=50)$ & 45.90 & & & & & \\
\hline
\end{tabular}

The data presented in Table 3 shows that the mean posttest knowledge score of working women in experimental group was 29.44 and 17.48 in comparison group with a mean difference of 11.96 . The computed ' $t$ ' value obtained (14.85) was found to be statistically significant at 0.05 level. 
Also the mean post test attitude scores of working women in experimental group was 100.16 and 84.10 in comparison group with a mean difference of 16.06. The computed ' $t$ ' value obtained (12.68) was found to be statistically significant at 0.05 level.

Furthermore, the mean post test expressed practices scores of working women in experimental group was 52.20 and 46.14 in comparison group with a mean difference of 6.06 . The computed ' $t$ ' value obtained (4.93) was found to be statistically significant at 0.05 level which shows that the mean difference in posttest knowledge, attitude, and expressed practices score of working women in experimental group and comparison group was a true difference but not by chance. It was concluded that the informational booklet was effective in enhancing the knowledge, developing favourable attitude and improving the practices.

Table 3 Comparison of posttest Knowledge, Attitude and Expressed Practices Scores in Experimental and comparison group

$\mathbf{N}=\mathbf{1 0 0}$

\begin{tabular}{|c|c|c|c|c|c|c|}
\hline \multicolumn{7}{|c|}{ Knowledge } \\
\hline Group & Mean & $\mathbf{M}_{\mathbf{D}}$ & $\mathbf{S D}_{\mathbf{D}}$ & S. $\mathbf{E}_{M D}$ & 't' & p value \\
\hline Experimental $(n=50)$ & 29.44 & & & & & \\
\hline & & 11.96 & 6.29 & 0.89 & 14.85 & $0.001^{*}$ \\
\hline Comparison $(n=50)$ & 17.48 & & & & & \\
\hline \multicolumn{7}{|c|}{ Attitude } \\
\hline Experimental $(n=50)$ & 100.16 & & & & & \\
\hline & & 16.06 & 8.74 & 1.64 & 12.68 & $0.001^{*}$ \\
\hline Comparison $(n=50)$ & 84.10 & & & & & \\
\hline \multicolumn{7}{|c|}{ Expressed Practices } \\
\hline Experimental $(n=50)$ & 52.20 & & & & & \\
\hline & & 6.06 & 9.46 & 1.74 & 4.93 & $0.001^{*}$ \\
\hline Comparison $(n=50)$ & 46.14 & & & & & \\
\hline
\end{tabular}

Table 4 Area Wise Mean, Modified Gain of Pretest and Posttest Knowledge Score in Experimental and Comparison Group

$\mathbf{N}=100$

\begin{tabular}{|c|c|c|c|c|c|c|c|}
\hline Group & $\begin{array}{c}\text { Areas of } \\
\text { Knowledge }\end{array}$ & $\begin{array}{l}\text { Max } \\
\text { score }\end{array}$ & $\begin{array}{l}\text { Pretest } \\
\text { Mean } \\
\end{array}$ & $\begin{array}{c}\text { Posttest } \\
\text { Mean } \\
\end{array}$ & $\begin{array}{l}\text { Actual gain } \\
\text { score }\end{array}$ & $\begin{array}{l}\text { Possible gain } \\
\text { score }\end{array}$ & $\begin{array}{c}\text { Modified } \\
\text { gain } \\
\text { score } \\
\end{array}$ \\
\hline \multirow{4}{*}{ Experimental $(n=50)$} & Concept & 06 & 3.02 & 5.18 & 2.16 & 2.98 & 0.72 \\
\hline & Risk factors & 09 & 4.14 & 7.66 & 3.52 & 4.86 & 0.72 \\
\hline & $\begin{array}{l}\text { Sign and } \\
\text { Symptoms }\end{array}$ & 02 & 0.90 & 1.70 & 0.80 & 1.10 & 0.73 \\
\hline & $\begin{array}{c}\text { Treatment } \\
\text { and } \\
\text { Prevention }\end{array}$ & 17 & 8.88 & 14.9 & 6.02 & 8.12 & 0.74 \\
\hline \multirow{4}{*}{ Comparison $(n=50)$} & Concept & 06 & 2.82 & 3.22 & 0.4 & 3.18 & 0.13 \\
\hline & Risk factors & 09 & 3.98 & 4.30 & 0.32 & 5.02 & 0.06 \\
\hline & $\begin{array}{c}\text { Sign and } \\
\text { symptoms }\end{array}$ & 02 & 0.86 & 0.94 & 0.08 & 1.14 & 0.07 \\
\hline & $\begin{array}{c}\text { Treatment and } \\
\text { prevention }\end{array}$ & 17 & 8.66 & 9.02 & 0.36 & 6.34 & 0.06 \\
\hline
\end{tabular}

The data presented in Table 4 reveals that in the experimental group, the maximum gain had been in the area of treatment and prevention of osteoporosis $(0.74)$ followed by sign and symptoms of osteoporosis (0.73), concept and risk factors of osteoporosis i.e.0.72.

Also in comparison group, minimal gain had been in the area of concept $(0.13)$ followed by sign and symptoms (0.07).

Table 5 Area Wise Mean, Mean Difference, Standard Deviation Difference and Standard Error of Mean Difference and't' Value of Pre Test and Post Test Knowledge Score in Experimental and Comparison Group

\begin{tabular}{|c|c|c|c|c|c|c|c|c|c|}
\hline Groups & Area & $\begin{array}{l}\text { Max } \\
\text { score }\end{array}$ & $\begin{array}{l}\text { Pretest } \\
\text { Mean }\end{array}$ & $\begin{array}{l}\text { Posttest } \\
\text { Mean }\end{array}$ & $\mathbf{M}_{\mathbf{D}}$ & $\mathbf{S D}_{\mathrm{D}}$ & $\mathbf{S E}_{\mathbf{M D}}$ & 't' & p value \\
\hline \multirow{4}{*}{$\begin{array}{l}\text { Experimental } \\
\text { Group }\end{array}$} & Concept & 06 & 3.02 & 5.18 & 2.16 & 1.67 & 0.22 & 9.14 & $0.001^{*}$ \\
\hline & Risk factors & 09 & 4.14 & 7.66 & 3.52 & 2.01 & 0.24 & 12.4 & $0.001 *$ \\
\hline & Sign and symptoms & 02 & 0.90 & 1.70 & 0.80 & 0.99 & 0.12 & 5.72 & $0.001 *$ \\
\hline & Treatment and & 15 & 8.88 & 14.9 & 6.02 & 2.93 & 0.41 & 14.5 & $0.001 *$ \\
\hline
\end{tabular}




\begin{tabular}{|c|c|c|c|c|c|c|c|c|c|}
\hline \multirow{4}{*}{$\begin{array}{l}\text { Comparison } \\
\text { Group }\end{array}$} & $\begin{array}{l}\text { Prevention } \\
\text { Concept }\end{array}$ & 06 & 2.82 & 3.22 & 0.40 & 0.78 & 0.24 & 3.62 & $0.0007^{*}$ \\
\hline & Risk factors & 09 & 3.98 & 4.30 & 0.32 & 0.71 & 0.35 & 3.18 & $0.0026^{*}$ \\
\hline & Sign and symptoms & 02 & 0.86 & 0.94 & 0.08 & 0.27 & 0.11 & 2.06 & $0.044^{*}$ \\
\hline & $\begin{array}{l}\text { Treatment and } \\
\text { Prevention }\end{array}$ & 15 & 8.66 & 9.02 & 0.36 & 0.80 & 0.46 & 3.17 & $0.002^{*}$ \\
\hline
\end{tabular}

$\overline{' t '(49)}=2.01$

"significant (p $\leq \mathbf{0 . 0 5})$

Data presented in Table 5 shows that in Experimental group, the ' $\mathrm{t}$ ' value computed in all the areas were found to be significant at 0.05 level of significance. Thus, it can be inferred that the informational booklet was effective in improving the knowledge of working women in all areas of knowledge regarding prevention of osteoporosis.

Also in comparison group, the ' $\mathrm{t}$ ' value computed in all the areas were found to be significant at 0.05 level of significance. Thus, it can be inferred that there was a significant gain in all areas of knowledge in comparison group though no intervention was given. The reason may be due to pretest sensitization and confounding variables such as time.

Table 6 Area Wise Mean, Modified Gain of Pre Test and Post Test Attitude Score in Experimental and Comparison Group

$\mathbf{N}=\mathbf{1 0 0}$

\begin{tabular}{|c|c|c|c|c|c|c|c|}
\hline Group & $\begin{array}{ll}\text { Areas } & \text { of } \\
\text { Knowledge }\end{array}$ & $\begin{array}{l}\text { Max } \\
\text { score }\end{array}$ & Pretest & Posttest & $\begin{array}{l}\text { Actual } \\
\text { gain score }\end{array}$ & $\begin{array}{l}\text { Possible } \\
\text { gain score }\end{array}$ & $\begin{array}{l}\text { Modified } \\
\text { gain score }\end{array}$ \\
\hline \multirow{4}{*}{$\begin{array}{c}\text { Experimental } \\
(n=50)\end{array}$} & Concept & 45 & 28.3 & 32.1 & 3.8 & 16.7 & 0.23 \\
\hline & Risk factors & 15 & 10.5 & 11.3 & 0.8 & 4.5 & 0.18 \\
\hline & $\begin{array}{l}\text { Sign and } \\
\text { Symptoms }\end{array}$ & 40 & 3.88 & 4.70 & 0.82 & 36.12 & 0.02 \\
\hline & $\begin{array}{l}\text { Treatment } \\
\quad \text { and } \\
\text { Prevention }\end{array}$ & 65 & 43.5 & 52.0 & 8.50 & 21.5 & 0.39 \\
\hline \multirow{4}{*}{ Comparison $(n=50)$} & Concept & 45 & 27.6 & 27.7 & 0.1 & 17.4 & 0.01 \\
\hline & Risk factors & 15 & 9.08 & 9.04 & 0.04 & 5.92 & 0.01 \\
\hline & $\begin{array}{l}\text { Sign and } \\
\text { symptoms }\end{array}$ & 40 & 4.18 & 4.12 & 0.06 & 35.82 & 0.002 \\
\hline & $\begin{array}{l}\text { Treatment } \\
\text { and } \\
\text { Prevention }\end{array}$ & 65 & 43.2 & 43.2 & 0 & 21.8 & 0 \\
\hline
\end{tabular}

The data presented in Table 6 reveals that in the experimental group, maximum gain had been in the area of treatment and prevention of osteoporosis $(0.39)$ followed by concept $(0.23)$. The dataalso reveals that no gain had been in the areas of attitude score in comparison group.

Table 7 Area Wise Mean, Mean Difference, $S_{D}$, Standard Error of Mean Difference and ' $t$ ' Value of Pre Test and Post Test Attitude Score in Experimental and Comparison Group $\mathbf{N}=\mathbf{5 0}$

\begin{tabular}{|c|c|c|c|c|c|c|c|c|c|}
\hline Groups & Areas of Attitude & $\begin{array}{l}\text { Max } \\
\text { score }\end{array}$ & $\begin{array}{l}\text { Pretest } \\
\text { Mean }\end{array}$ & $\begin{array}{l}\text { Posttest } \\
\text { Mean }\end{array}$ & $\mathbf{M}_{\mathbf{D}}$ & $\mathbf{S D}_{\mathbf{D}}$ & $\mathbf{S E}_{\mathbf{M D}}$ & 't $t$ ' & p value \\
\hline \multirow{3}{*}{$\begin{array}{l}\text { Experimental } \\
\text { Group }\end{array}$} & Concept & 45 & 28.32 & 32.14 & 3.82 & 4.53 & 0.78 & 5.96 & $0.001^{*}$ \\
\hline & $\begin{array}{l}\text { Sign and } \\
\text { symptoms }\end{array}$ & 40 & 3.88 & 4.70 & 0.82 & 1.19 & 0.15 & 4.87 & $0.001 *$ \\
\hline & $\begin{array}{l}\text { Treatment and } \\
\text { Prevention }\end{array}$ & 65 & 43.46 & 52.02 & 8.56 & 5.35 & 0.90 & 11.32 & $0.001^{*}$ \\
\hline \multirow{3}{*}{$\begin{array}{l}\text { Comparison } \\
\text { Group }\end{array}$} & Concept & 45 & 27.56 & 27.70 & 0.14 & 0.97 & 0.60 & 1.02 & $0.31^{\mathrm{NS}}$ \\
\hline & Risk factors & 15 & 9.08 & 9.04 & 0.04 & 0.95 & 0.39 & 0.29 & $0.76^{\mathrm{NS}}$ \\
\hline & $\begin{array}{l}\text { Sign and } \\
\text { symptoms }\end{array}$ & 40 & 4.18 & 4.12 & 0.06 & 0.31 & 0.09 & 1.35 & $0.18^{\mathrm{NS}}$ \\
\hline
\end{tabular}


Data presented in Table 7 shows that in experimental group ' $t$ ' value obtained in all the areas was found to be significant at 0.05 level of significance. Thus, it can be inferred that the informational booklet was effective in developing the attitude of working women in all areas.

Also, in comparison group, 't' value computed was found to be non-significant at 0.05 level of significance. Thus, it can be concluded that there was no development of attitude among working women in comparison group.

Table 8 Area Wise Mean, Modified Gain of Pretest and Posttest Expressed Practice Score in Experimental and Comparison Group

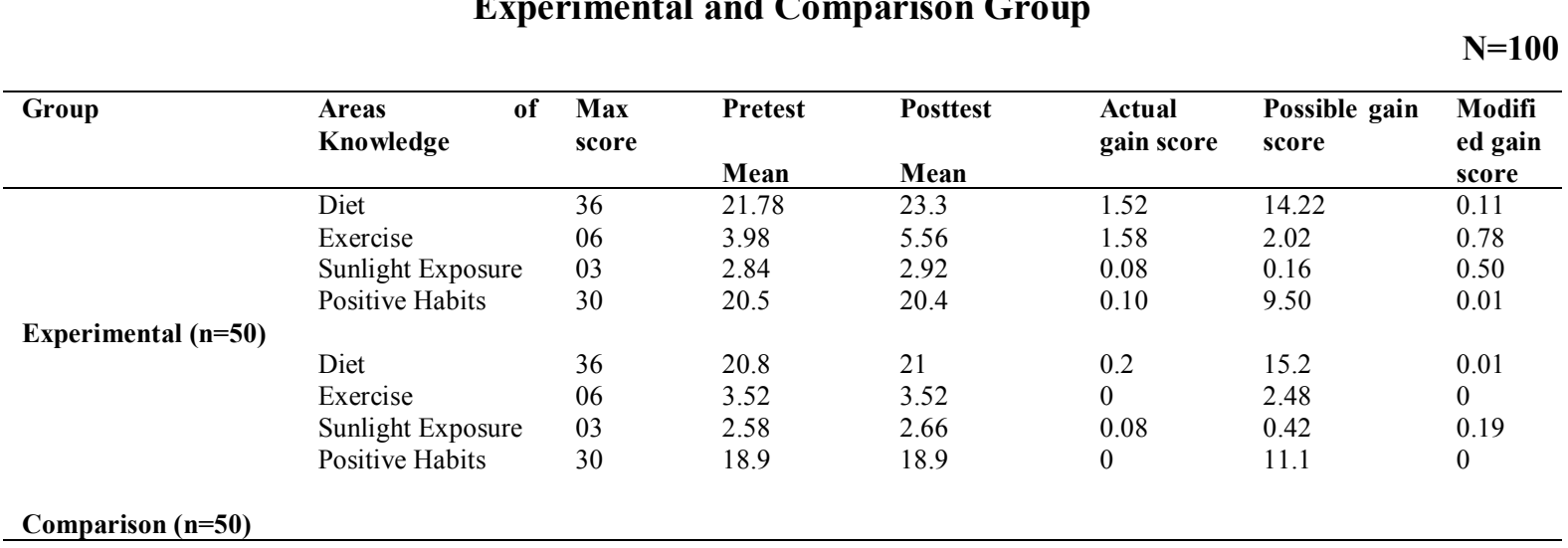

The data presented in Table 8 reveals that in experimental group the maximum gain had been in the area of exercise $(0.78)$ followed by sunlight exposure $(0.50)$.

The data also reveals that no gain had been in the areas of expressed practices score in comparison group.

Table 9 Area Wise Mean, Mean Difference, Standard Deviation Difference, Standard Error of Mean Difference and ' $t$ ' Value of Pre Test and Post Test Expressed Practice Score of Working Woman in Experimental and Comparison Group

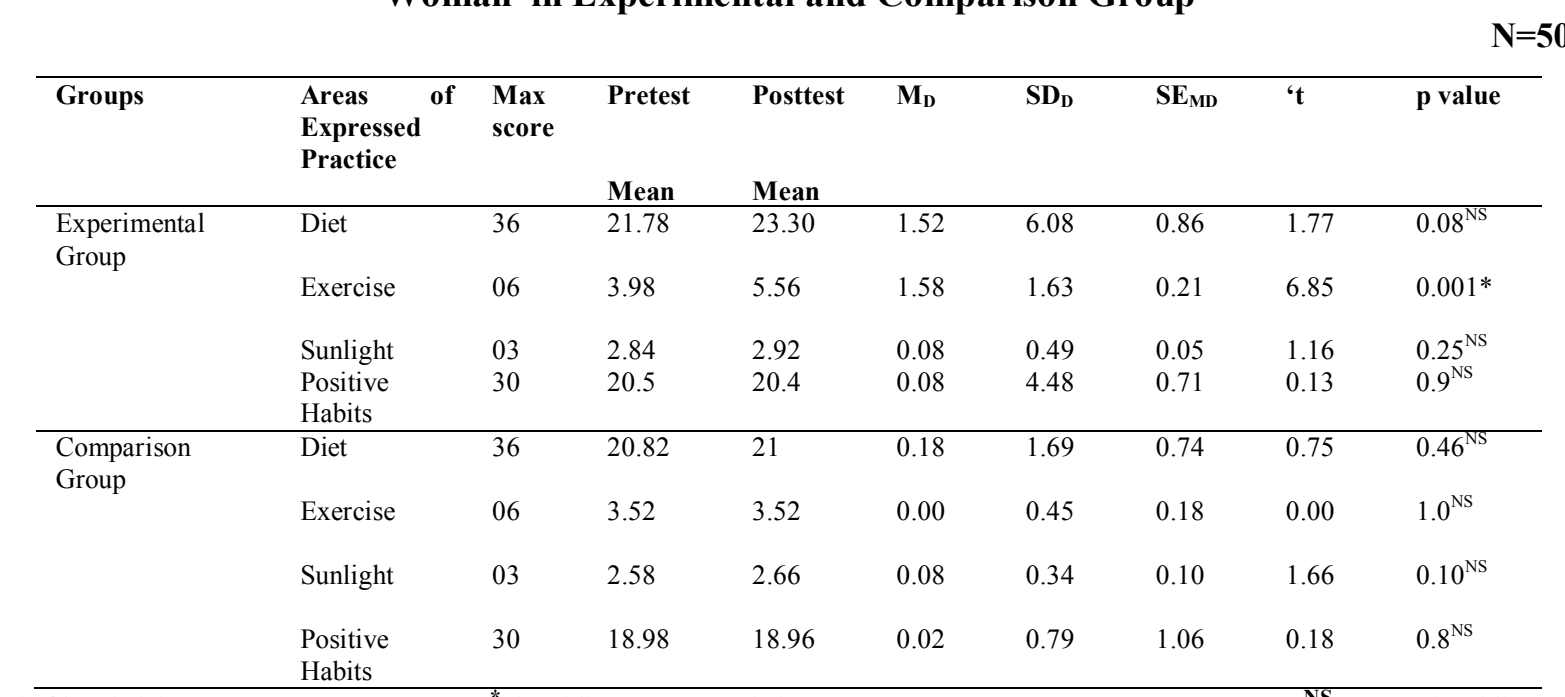

$\mathbf{t}^{\prime}(\mathbf{4 9 )}=\mathbf{2 . 0 1} \quad$ significance $(\mathrm{p} \leq \mathbf{0 . 0 5})$

NS-Not significant

Data presented in Table 9 shows that in Experimental group, $t$ ' value in all the areas was found to be non-significant at 0.05 level of significance except exercise. Thus, it can be inferred that the informational booklet was not effective in improving the expressed practices in the areas of expressed practices except in exercise.

Also in comparison group, 't' value in all the areas was found to be non significant at 0.05 level of significance. Thus, it can be inferred that there was no improvement in the expressed practices in the areas of expressed practices in comparison group.

Table 10 Correlation Between Posttest Knowledge, Attitude and Expressed Practices Scores in Experimental Group 


\begin{tabular}{lllc} 
& & & Knowledge \\
\hline Correlation & Attitude & Expressed practice \\
\hline Knowledge & 0.59 & - & - \\
& $0.0001^{*}$ & -0.131 & - \\
Attitude & - & $0.36^{\mathrm{NS}}$ & 0.15 \\
& - & - & $0.29^{\mathrm{NS}}$ \\
\hline
\end{tabular}

'r' (48) $=0.279$

Table 11 Chi-Square Value Showing Association of Levels of Post Test Knowledge, Attitude and Expressed Practices with Selected Personal Variables in Experimental Group

$\mathbf{N}=\mathbf{5 0}$

\begin{tabular}{|c|c|c|c|c|c|c|c|c|c|c|}
\hline S.No & Personal variables & \multicolumn{3}{|c|}{ Level of knowledge } & \multicolumn{3}{|c|}{ Level of attitude } & \multicolumn{3}{|c|}{ Level of expressed practices } \\
\hline & & $\chi^{2}$ & $\mathrm{df}$ & $\mathrm{P}$ value & $\chi^{2}$ & $\mathrm{df}$ & $\mathrm{P}$ value & $\chi^{2}$ & $\overline{\mathrm{Df}}$ & $\mathrm{P}$ value \\
\hline 1. & Age & 11.19 & 6 & $0.08^{\mathrm{NS}}$ & 0.53 & 3 & $0.91^{\mathrm{NS}}$ & 1.03 & 3 & $0.79^{\mathrm{NS}}$ \\
\hline 2. & Religion & 7.55 & 2 & 0.02 & 10.04 & 1 & $0.002^{*}$ & 0.96 & 1 & $0.33^{\mathrm{NS}}$ \\
\hline 3. & $\begin{array}{l}\text { Educational } \\
\text { qualification }\end{array}$ & 1.73 & 4 & $0.79^{\mathrm{NS}}$ & 0.83 & 2 & $0.66^{\mathrm{NS}}$ & 5.51 & 2 & $0.06^{\mathrm{NS}}$ \\
\hline 4. & $\begin{array}{l}\text { Family Income per } \\
\text { month }\end{array}$ & 2.42 & 6 & $0.88^{\mathrm{NS}}$ & 4.36 & 3 & $0.23^{\mathrm{NS}}$ & 1.89 & 3 & $0.59^{\mathrm{NS}}$ \\
\hline 5. & Place of residence & 1.06 & 2 & $0.59^{\mathrm{NS}}$ & 3.01 & 1 & $0.08^{\mathrm{NS}}$ & 0.57 & 1 & $0.45^{\mathrm{NS}}$ \\
\hline 6. & Dietary habits & 0.83 & 2 & $0.66^{\mathrm{NS}}$ & 0.25 & 1 & $0.06^{\mathrm{NS}}$ & 0.34 & 1 & $0.56^{\mathrm{NS}}$ \\
\hline 7. & Marital status & 0.79 & 2 & $0.67^{\mathrm{NS}}$ & 0.26 & 1 & $0.61^{\mathrm{NS}}$ & 1.33 & 1 & $0.25^{\mathrm{NS}}$ \\
\hline 8. & $\begin{array}{l}\text { History of } \\
\text { osteoporosis in the } \\
\text { family }\end{array}$ & 2.05 & 2 & $0.36^{\mathrm{NS}}$ & 3.47 & 1 & $0.06^{\mathrm{NS}}$ & 2.09 & 1 & $0.15^{\mathrm{NS}}$ \\
\hline 9. & $\begin{array}{l}\text { Are } \mathrm{u} \text { taking any } \\
\text { medications }\end{array}$ & 0.23 & 2 & $0.89^{\mathrm{NS}}$ & 0.66 & 1 & $0.42^{\mathrm{NS}}$ & 0.39 & 1 & $0.53^{\mathrm{NS}}$ \\
\hline 10. & $\begin{array}{l}\text { Any family } \\
\text { member as health } \\
\text { Professional }\end{array}$ & 0.74 & 2 & $0.69^{\mathrm{NS}}$ & 0.72 & 1 & $0.39^{\mathrm{NS}}$ & 0.90 & 1 & $0.34^{\mathrm{NS}}$ \\
\hline 11. & $\begin{array}{l}\text { Source of } \\
\text { knowledge related } \\
\text { to } \\
\text { prevention } \\
\text { osteoporosis } \\
\end{array}$ & 1.92 & 2 & $0.38^{\mathrm{NS}}$ & 5.25 & 1 & $0.02^{*}$ & 0.50 & 1 & $0.48^{\mathrm{NS}}$ \\
\hline
\end{tabular}

$\chi^{2}(1)=3.84, \chi^{2}(2)=5.99, \chi^{2}(3)=7.82, \chi^{2}(4)=9.49, \chi^{2}(6)=12.59 *$ significant $(p \leq 0.05) \quad{ }^{\text {NS }}$ - not significant $(\mathbf{p}>0.05)$

Data given in Table 11 shows that chi square computed between posttest level of knowledge and religion $\left(\chi^{2}=0.02\right)$ was found to be statistically significant at 0.05 level. This indicates level of knowledge of working women was associated with their religion. This shows that among Hindus, majority (93\%) had very good knowledge ascompared to $71.45 \%$ Sikhs.

Similarly, there was a significant association of post test level of attitude with religion $\left(\chi^{2} 10.04\right)$ and source of knowledge $\left(\chi^{2}=0.02\right)$ related to prevention of osteoporosis in experimental group suggesting that level of attitude of working women was dependent on their religion and source of knowledge related to prevention of osteoporosis. This reveals that among Hindus majority (83.7\%) had favourable attitude as compared to $71.4 \%$ Sikhs who had moderately favourable attitude.

Similarly majority of working women having source of knowledge (94.4\%) had favouarble attitude as compared to those who were not having any source of knowledge regarding prevention of osteoporosis.

The data further shows that chi square computed between posttest level of expressed practices and selected personal variables were found to be statistically not significant at 0.05 level. This indicates that level of posttest level of expressed practices was not associated with personal variables of working women.

\section{Discussion}


The findings of the study conducted by $\mathbf{K}$ Pande et al shows that majority of patients (74\%) identified media as the most common source of knowledge and $25 \%$ of them reported family doctor as their source of knowledge while in the present study only $28 \%$ of the working women had any source of knowledge regarding prevention of osteoporosis. Among them, 21 out of $28(75 \%)$ had media(Television, Radio, internet, newspaper and books) as source of knowledge followed by 5 out of $28(17.9 \%)$ had other source of knowledge and 2 out of $28(7.1 \%)$ had clinics as source of knowledge. ${ }^{5}$

In the present study, mean post -test knowledge score of experimental group (29.44 \pm 3.52$)$ was significantly higher $\left(\mathrm{p}=0.0001^{*}\right)$ than the mean post-test knowledge score of comparison group $(17.48 \pm 4.40)$. This finding is consistent with DavoudShojaeizadeh et al. whoreported that mean awareness score of case group $(21.38 \pm 2.25)$ was significantly higher $(\mathrm{p}<0.001)$ than control group $(14.46 \pm 3.22)$ after the administration of educational intervention.

The present study revealed a significant increase $\left(\mathrm{t}=15.79, \mathrm{p}=0.0001^{*}\right)$ in knowledge of experimental group after administration of informational booklet. This finding was consistent with another study conducted by L. Abushaikha., et. Al (2009) in which Pretest and posttest analysis revealed a significant overall increase in osteoporosis knowledge scores among the students after the health education sessions (mean score pretest $=$ 24.1; posttest $=29.8, t=9.6, P<0.001)^{8}$

The findings of the present study revealed that there is a significant increase in knowledge level after the administration of informational booklet. Working women had below average knowledge (54\%) before intervention and became $(0 \%)$ after intervention, while those who had very good knowledge (4\%) before intervention, became $90 \%$ after intervention which was consistent with the study findings of Eman M. Mahfouz $^{9}$ which shows that there is significant increase in knowledge level after health education. Students who had low knowledge level before health education were $85.7 \%$ and became $8 \%$ only after health education, while those who had high knowledge level were $6.5 \%$ before health education and they become $86.2 \%$ after health education.

In the present study, area wise highest mean percentage of knowledge score after the administration of informational booklet was in the area of treatment and prevention $(87.7 \%)$ followed by concept of osteoporosis $(86.3 \%)$. The least mean percentage was obtained in the area of risk factors $(85.1 \%)$ and sign and symptoms of osteoporosis (85\%). These findings were inconsistent with that of Premina Mukkolath ${ }^{10}$, whoreported thatthe highest mean percentage (51.67\%) in the area of "causes and risk factors of osteoporosis", $48.33 \%$ in the area of "osteoporosis-preventive practices" and $45 \%$ in the area of "Disease manifestations, complications and diagnosis of osteoporosis." The least mean percentage $(40.60 \%)$ was obtained in the area of "concept of osteoporosis" after the administration of self instructional module.

In the present study, mean post -test attitude score of experimental group $(100.16 \pm 6.78)$ was significantly higher $\left(\mathrm{p}=0.0001^{*}\right)$ than the mean post-test attitude score of comparison group $(84.10 \pm 5.85)$. This finding is consistent with DavoudShojaeizadeh et al. ${ }^{7}$ whoreported that mean attitude score of case group [perceived susceptibility $(14.20 \pm 4.45$,perceived severity $(17.24 \pm 4.30)$ ] was significantly higher $(p<0.001)$ than controlgroup $(\mathrm{p}<0.001)$ after the administration of educational intervention.

In the present study, expressed practices of working women were significantly improved $(\mathrm{t}=2.05$, $\mathrm{p}=0.04$ ) in experimental group after administration of informational booklet. This finding is consistent with study conducted by Elizabeth BryneRodzik (2008) ${ }^{4}$ in which the total OSES (osteoporosis self-efficacy scale) score increased from pretest $($ mean $=1425.54, \mathrm{sd}=36.11)$ to post-test $($ mean $=1629.23$, $\mathrm{sd}=31.47)$ and the change was statistically significant $(t=9.08, \mathrm{p}<.05)$. These results also demonstrate that the participants reported higher overall post-test self-efficacy levels than pre-test. Thus, the study concluded that the osteoporosis educational program positively influenced participants' belief that they could adopt lifestyle behavioral changes, specifically in calcium intake and exercise.

\section{Recommendations}

The study can be replicated on a large sample in other settings to validate the findings and make generalization.

\section{Conclusion}

Informational booklet is an effective strategy in enhancing knowledge, developing favourable attitude, and improving practices of working women regarding prevention of osteopororosis.

\section{Acknowledgement}

With a deep sense of gratitude I would like to acknowledge my guide Mrs. VinayKumari, Assistant Professor, MM College of Nursing whose zealous interest, sustained availability, timely support and expert guidance made it possible for me to pursue and complete this study. I also take the opportunity to record my sense of reverence to my co-guide Ms. Mercy Madanlal, Assistant Professor, MM College of Nursing for her constant motivation and guidance. 
I take this opportunity to express my sincere gratitude to Dr. (Mrs.) JyotiSarin, Director- Principal, M M College of Nursing for guiding me and providing facilities and support for conducting the present study.

Lastly and most importantly I am forever grateful to everybody who was important to the successful realization of the study.

\section{Reference}

[1] Warburton Darren ER ,Crystal Whitney Nicol,Stephanie N Gatto, Shannon Bredin SD. Cardiovascular disease and osteoporosis: Balancing risk management. Vasc Health Risk Manag .2007Oct; 3(5). Available from: www.ncbi.nlm.nih.gov.

[2] NBI Global Reach: Osteoporosis around the World. Available from: www.nbihealth.com/t-globalreach.aspx.

[3]. Dhakal Sharma Kalpana, Dhakal Shankar, AryalBijay. Prevalence of Osteoporosis among Middle Aged Women in Chitwan District of Nepal.Intern J Phar \& Bio Arch. 2012; 3(4):779-782.

[4] Rodzik Byrne Elizabeth. Osteoporosis Education in College-Age Women [M.sc Nursing theses].Eastern Michigan University; 2008.

[5] Pande K, PandeSonali, Tripathi S, Kanoi R, Thakur A, Patle S . Poor Knowledge about Osteoporosis in learned Indian Women. JAPI. 2005May; 53: 433-436.

[6] Edmonds Ellen T, Turner Lori W.Osteoporosis Prevention among College Students: Strategies for Health Professionals [PhD thesis]. University of central Ankasas.

[7] ShojaeizadehDavoud, SadeghiRoya, JavadTarrahi Mohammad, AsadiMojgan, safari Hossein, LashgararaBehnam. The effect of educational intervention on prevention of osteoporosis through Health Belief Model (HBM) in volunteers of Khorramabad city Health centre.Annuals of Biological Research. 2012; 3 (1):300-307.

[8] Abushaikha L, Omran S, Barrouq L. Osteoporosis knowledge among female school students in Jordan. Eastern Mediterranean Health Journal. 2009;15(4):906-911.

[9] Mahfouz Eman M, KamelGirgisEmad, MosalemFadiaAbd El- Hameed, SamehEman. Osteoporosis-related lifestyle choices and knowledge among adolescent females in el-minia city, Egypt. El-Minia Med. 2007 Jan; 18(1):29-41.

[10] MukkolathPramina. Effectiveness of a self-instructional Module on Knowledge of prevention of osteoporosis among working women[M.sc Nursing Thesis]; 2005. 